Utah State University

DigitalCommons@USU

T.W. "Doc" Daniel Experimental Forest

Quinney Natural Resources Research Library,

S.J. and Jessie E.

$12-2005$

\title{
Soil carbon distribution and quality in a montane rangeland forest mosaic in northern Utah
}

\author{
Helga Van Miegrot \\ Janis L. Boettinger \\ Michelle A. Baker \\ Julia Nielson \\ Dave Evans
}

Alex Stum

Follow this and additional works at: https://digitalcommons.usu.edu/docdan

\section{Recommended Citation}

H.V. Miegrot et al. 2005. Soil carbon distribution and quality in a montane rangeland-forest mosaic in northern Utah. Forest Ecology and Management. 220 (1-3) 284-299

This Article is brought to you for free and open access by the Quinney Natural Resources Research Library, S.J. and Jessie E. at DigitalCommons@USU. It has been accepted for inclusion in T.W. "Doc" Daniel Experimental Forest by an authorized administrator of DigitalCommons@USU.

For more information, please contact

digitalcommons@usu.edu.

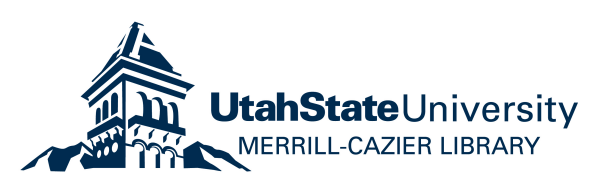




\title{
Utah State University
}

\section{DigitalCommons@USU}

T.W. "Doc" Daniel Experimental Forest

Quinney Natural Resources Research Library, S.J. and Jessie E.

$12-2005$

\section{Soil carbon distribution and quality in a montane rangeland forest mosaic in northern Utah}

\author{
Helga Van Miegrot
}

Janis L. Boettinger

Michelle A. Baker

Julia Nielson

Dave Evans

Alex Stum

Follow this and additional works at: https://digitalcommons.usu.edu/docdan

\section{Recommended Citation}

H.V. Miegrot et al. 2005. Soil carbon distribution and quality in a montane rangeland-forest mosaic in northern Utah. Forest Ecology and Management. 220 (1-3) 284-299

This Article is brought to you for free and open access by the Quinney Natural Resources Research Library, S.J. and Jessie E. at DigitalCommons@USU. It has been accepted for inclusion in T.W. "Doc" Daniel Experimental Forest by an authorized administrator of DigitalCommons@USU. For more information, please contact dylan.burns@usu.edu.

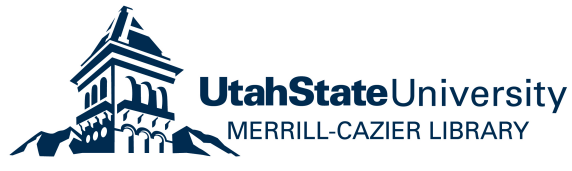




\title{
Soil carbon distribution and quality in a montane rangeland-forest mosaic in northern Utah
}

\author{
Helga Van Miegroet ${ }^{\mathrm{a}, *}$, Janis L. Boettinger ${ }^{\mathrm{b}}$, Michelle A. Baker ${ }^{\mathrm{c}}$, \\ Julia Nielsen ${ }^{c}$, Dave Evans ${ }^{\mathrm{a}}$, Alex Stum ${ }^{\mathrm{b}}$ \\ ${ }^{a}$ Department of Forest, Range, and Wildlife Sciences, Utah State University, 5230 Old Main Logan, UT 84322-5230, USA \\ ${ }^{\mathrm{b}}$ Department of Plants, Soils, and Biometeorology, Utah State University, Logan, UT 84322-4820, USA \\ ${ }^{\mathrm{c}}$ Department of Biology, Utah State University, Logan, UT 84322-5305, USA
}

\begin{abstract}
Relatively little is known about soil organic carbon (SOC) dynamics in montane ecosystems of the semi-arid western U.S. or the stability of current SOC pools under future climate change scenarios. We measured the distribution and quality of SOC in a mosaic of rangeland-forest vegetation types that occurs under similar climatic conditions on non-calcareous soils at Utah State University's T.W. Daniel Experimental Forest in northern Utah: the forest types were aspen [Populus tremuloides] and conifer (mixture of fir [Abies lasiocarpa] and spruce [Picea engelmannii]); the rangeland types were sagebrush steppe [Artemisia tridentata], grass-forb meadow, and a meadow-conifer ecotone. Total SOC was calculated from OC concentrations, estimates of bulk density by texture and rock-free soil volume in five pedons. The SOC quality was expressed in terms of leaching potential and decomposability. Amount and aromaticity of water-soluble organic carbon (DOC) was determined by water extraction and specific ultra violet absorbance at $254 \mathrm{~nm}$ (SUVA) of leached DOC. Decomposability of SOC and DOC was derived from laboratory incubation of soil samples and water extracts, respectively.

Although there was little difference in total SOC between soils sampled under different vegetation types, vertical distribution, and quality of SOC appeared to be influenced by vegetation. Forest soils had a distinct $\mathrm{O}$ horizon and higher SOC concentration in near-surface mineral horizons that declined sharply with depth. Rangeland soils lacked O horizons and SOC concentration declined more gradually. Quality of SOC under rangelands was more uniform with depth and SOC was less soluble and less decomposable (i.e., more stable) than under forests. However, DOC in grass-forb meadow soils was less aromatic and more bioavailable, likely promoting $\mathrm{C}$ retention through cycling. The SOC in forest soils was notably more leachable and decomposable, especially near the soil surface, with stability increasing with soil depth. Across the entire dataset, there was a weak inverse relationship between the decomposability and the aromaticity of DOC. Our data indicate that despite similar SOC pools, vegetation type may affect SOC retention capacity under future climate projections by influencing potential SOC losses via leaching and decomposition.
\end{abstract}

(C) 2005 Elsevier B.V. All rights reserved.

Keywords: C sequestration; Decomposition; Leaching; Sagebrush; Forest soils; Soil genesis

\footnotetext{
* Corresponding author. Tel.: +1 435797 3175; fax: +1 4357973796.

E-mail address: helgavm@cc.usu.edu (H. Van Miegroet).
} 


\section{Introduction}

Terrestrial ecosystems mitigate increases in atmospheric $\mathrm{CO}_{2}$ via carbon (C) sequestration in vegetation biomass and soil organic carbon (SOC). While $\mathrm{C}$ stored in aboveground plant biomass and detritus can be rapidly released following disturbance (e.g., wild fire, land clearing), $\mathrm{C}$ in the mineral soil responds more slowly to such disturbances (e.g., Johnson and Curtis, 2001; Guo and Gifford, 2002). Temperate, boreal, and low-latitude forests are significant $\mathrm{C}$ sinks (Post et al., 1982; Jobbagy and Jackson, 2000) followed by temperate grasslands (e.g., Burke et al., 1989b). Desert shrub ecosystems sequester less organic carbon (OC) than forests or grasslands, but a larger proportion of the OC is stored as SOC (Houghton, 1995). While the influence of vegetation and climate on $\mathrm{C}$ sequestration in aboveground biomass is well-studied, much less is known about SOC dynamics (Lal et al., 1997), or about the $\mathrm{C}$ sink strength of montane ecosystems of the semi-arid West (Schimel et al., 2002), even though ecosystems such as these occupy $>1.6$ million $\mathrm{km}^{2}$ globally (Bailey, 1998).

The SOC pool size and distribution reflect past C inputs and long-term accumulation processes relative to the cumulative hydrologic and gaseous $\mathrm{C}$ losses from the soil. Vegetation type and productivity influence $\mathrm{C}$ input rates and distribution in the soil. In forests, $<50 \%$ of net primary productivity (NPP) is allocated to roots (Coleman, 1976; Swift et al., 1979; Raich and Nadelhoffer, 1989), and OC additions to the soil occur chiefly via litterfall to the soil surface resulting in the formation of distinct $\mathrm{O}$ horizons. In contrast, most $\mathrm{C}$ allocation in shrubs and grasses is to roots (Coleman, 1976; Swift et al., 1979; Tiedeman, 1987), belowground C storage comprises most of the ecosystem OC (e.g., Prichard et al., 2000), and OC addition occurs mainly via fine root turnover in the near-surface mineral soil horizons (Swift et al., 1979; Knight, 1991), resulting in limited surficial litter accumulation. Differences in vegetation type and the mode of $C$ input to the soil further impact SOC quality (e.g., Barth and Klemmedson, 1982; Johnson, 1995; Quideau et al., 2001). Such differences in SOC distribution and dynamics among vegetation types are often reflected in divergent soil forming processes and horizon properties (e.g., Foth, 1984; Quideau and Bockheim, 1996). Conifer forests generate litter that is relatively slow to decompose, but tends to result in the production of highly soluble organic acids (Hongve et al., 2000), mostly fulvic acids (Kononova, 1966 as cited in Knight, 1991; Stevenson, 1982; Quideau and Bockheim, 1996), involved in the podzolization process. The fine root turnover of grasses tends to produce less-soluble humic acids and more stable humins (Stevenson, 1982; Anderson and Coleman, 1985), responsible for the formation of thick and distinct A horizons and Mollisols under prairies (e.g., Foth, 1984).

It is not clear to what extent the above patterns in SOC distribution and dynamics among broad vegetation types also persist in seasonally dry ecosystems, where NPP, decomposition and hydrologic fluxes are limited by water availability (Knight, 1991). There is evidence that changes in temperature and/or moisture or disturbances may induce SOC quality changes, even for a given vegetation type or soil substrate (Homann and Grigal, 1992; Amelung et al., 1997), which in turn may influence SOC storage (Jackson et al., 2002), SOC stability, or potential for C losses via leaching or decomposition (Anderson and Coleman, 1985; Zech et al., 1989; Homann and Grigal, 1992; Christ and David, 1996). On a global scale, climatic control of $\mathrm{C}$ dynamics is thought to lead to equilibrium SOC levels along broad temperature and precipitation gradients (e.g., Post et al., 1982; Kirschbaum, 1995). This would imply that vegetation type has limited impact on $\mathrm{C}$ sequestration potential of soils within a certain climatic region.

Seasonally dry montane ecosystems of the Intermountain West (IMW) are typified by structurally heterogeneous forest-rangeland mosaics. Yet, relatively little is known about SOC quality and dynamics in semi-arid systems or their variability across the landscape. To that end, we initiated a pilot study in Utah State University's T.W. Daniel Experimental Forest (TWDEF) in northern Utah, where a mosaic of forest (conifer and aspen) and rangeland (grass-forb and sagebrush) ecosystems typical of the IMW, occurs on non-calcareous soils under similar climatic conditions. The objective was to determine whether meaningful differences existed in the quantity, distribution, and quality of SOC in soils found under different vegetation types. Such data could provide valuable information on potential variability in $\mathrm{C}$ storage and retention in semi-arid environments, and the stability of the SOC pools under changing 
climate. To represent a longer term $\mathrm{C}$ sink, we focused our investigation mainly on the $\mathrm{OC}$ in mineral soil horizons, which are generally less responsive to disturbances (Johnson and Curtis, 2001; Guo and Gifford, 2002). Furthermore, in defining SOC quality, we focused on function rather than operational fractionations, and specifically considered decomposition and leaching potential of SOC. These characteristics are critical to stability and retention of SOC as they will influence $\mathrm{C}$ losses as $\mathrm{CO}_{2}$ via microbial decomposition and as dissolved organic $\mathrm{C}$ (DOC) via leaching.

\section{Materials and methods}

\subsection{Study site}

The TWDEF is located at an elevation of $2600 \mathrm{~m}$, approximately $30 \mathrm{~km}$ NE of Logan, Utah $\left(41.86^{\circ} \mathrm{N}\right.$, $\left.111.50^{\circ} \mathrm{W}\right)$. Average annual precipitation is $950 \mathrm{~mm}$, $80 \%$ of which accumulates as snow. Snowmelt typically occurs from mid-May to mid-June. Monthly rainfall is low between May and October, with lowest monthly precipitation $(<2 \mathrm{~cm})$ typically occurring in
July. Average low temperature is around $-10{ }^{\circ} \mathrm{C}$ in January; highest mean monthly temperature $\left(14.5^{\circ} \mathrm{C}\right)$ occurs in July (Schimpf et al., 1980; Skujins and Klubek, 1982). Summer grazing by cattle and sheep has occurred since the late 1800s (Schimpf et al., 1980) but was greatly reduced coincident with fire suppression since 1910 (Wadleigh and Jenkins, 1996). There is ample evidence in the literature that unless areas are severely overgrazed, few consistent changes in SOC occur (Manley et al., 1995; Bruce et al., 1999). Hence, we do not consider past grazing history a significant driver of SOC accumulation in our study area. Following an increase in fire frequency during the 1856-1909 settlement period, fire frequencies have significantly declined, and there is no evidence of fire in the area since 1910 (Wadleigh and Jenkins, 1996).

Our study was conducted in a 150 ha area with a mosaic of vegetation communities, all in close proximity to each other and characterized by similar elevation, aspect, climate, geomorphology, and geology (Fig. 1). Forested communities include aspen forest [Populus tremuloides Michx] and conifer forest, predominantly Engelmann spruce [Picea engelmannii Parry] and subalpine fir [Abies lasiocarpa (Hook)

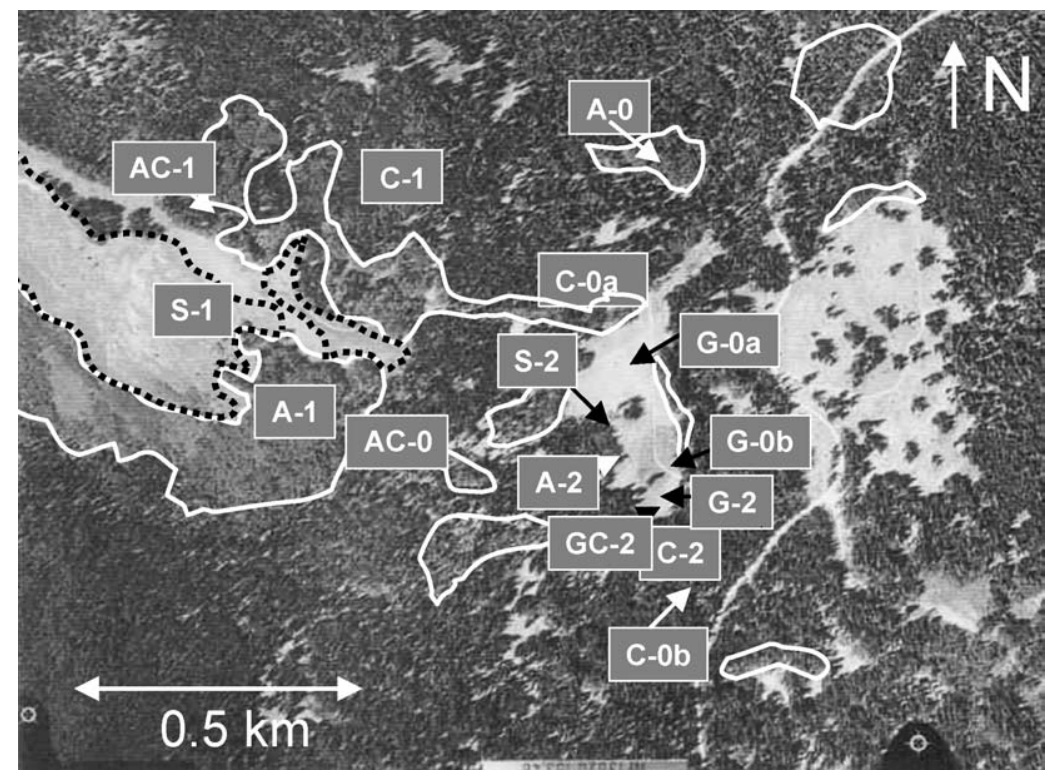

Fig. 1. Air photo of the T.W. Daniel Experimental Forest showing locations of the pedons [A, Aspen; AC, Mixed Aspen-Conifer; C, Conifer; G, Grass-Forb; GC, Grass-Conifer ecotone; S, Sagebrush]. Solid lines indicate boundaries of the aspen forest; dotted lines surround sagebrush steppe. 
Nutt], and lodgepole pine [Pinus contorta] stands. Non-forested communities include open meadows consisting of a mixture of grasses and forbs, and areas dominated by sagebrush [Artemisia tridentata].

The soils in the study area are carbonate-free and generally well drained, formed in eolian deposits overlying residuum and colluvium from the Wasatch formation (tertiary: middle and lower Eocene) dominated by roughly stratified, poorly sorted conglomerate a few hundred meters thick (Dover, 1995). This allowed us to focus on SOC dynamics without the interference of inorganic $\mathrm{C}$ (carbonates).

\subsection{Sampling and analysis}

A soil survey of TWEDF conducted by Utah State University's Soil Genesis, Morphology, and Classification course started in September 2000 and is ongoing. Soil pedons representative of major vegetation types and landscape components were exposed by manual excavation. Soil morphology was described following standards methods (Soil Survey Division Staff, 1993), including horizon depth, color, texture, structure, and volume of rock fragments. Six pedons were described in September 2000 under mixed spruce-fir conifer (C-0a, C-0b), aspen (A-0), mixed aspen-conifer (AC-0), and grass-forb meadow (G-0a, G0-b). In September 2001, four pedons were described under conifer (C-1), aspen (A-1), mixed aspen-conifer (AC-1), and sagebrush (S-1), and the near-surface mineral horizons were sampled for further analysis. In September 2002, five pedons under conifer (C-2), aspen (A-2), grass-forb meadow (G-2), sagebrush (S-2), and the shaded ecotone between grass-forb meadow and conifer (GC-2) were described and sampled by genetic horizon to $\geq 129 \mathrm{~cm}$ soil depth (Fig. 1).

Genetic horizon samples from 2002 were air-dried and sieved $<2 \mathrm{~mm}$, and selected chemical and physical analyses were performed. Exchangeable base cations were extracted with $1 \mathrm{M} \mathrm{NH}_{4} \mathrm{OAC}$ at pH 7.0 using a vacuum extractor (Soil Survey Laboratory Staff, 1996) and determined using and inductively coupled plasma spectrometer (ICP) (Iris Advantage, Thermo Electron, Madison, WI). Particle size distribution (PSD) was determined by wet sieving and pipette analysis (Gee and Bauder, 1986) after removal of organic matter with $5 \% \mathrm{NaOCl}$ adjusted to
pH 9.5 with $\mathrm{HCl}$. Total C (assumed to equal SOC in non-calcareous soils) and total $\mathrm{N}$ concentrations were determined by dry combustion using a $\mathrm{CHN}$ analyzer (Leco CHN 1000, Leco Corp., St. Joseph, MI). Bulk density of the $<2 \mathrm{~mm}$ fraction was estimated according to texture $\left(1.2 \mathrm{Mg} \mathrm{m}^{-3}\right.$ silt loam surface horizon; $1.3 \mathrm{Mg} \mathrm{m}^{-3}$ silt loam subsurface horizon, loam; $1.4 \mathrm{Mg} \mathrm{m}^{-3}$ clay loam, silty clay loam; $1.5 \mathrm{Mg} \mathrm{m}^{-3}$ sandy loam; $1.6 \mathrm{Mg} \mathrm{m}^{-3}$ loamy sand). The total $\mathrm{C}$ pools for each genetic horizon were calculated by multiplying $\mathrm{C}$ concentration, bulk density, horizon thickness, and the volume fraction of rock-fragment free soil by a unit conversion factor. Total $\mathrm{C}$ for the whole pedon was calculated by summing the $\mathrm{C}$ content for all horizons to the depth of sampling.

The soil organic matter (SOM) content was measured as mass loss-on-ignition (Nelson and Sommers, 1996) on a representative subsample from each genetic soil horizon sampled in 2002 and the near-surface horizons sampled in 2001. Water-soluble organic $\mathrm{C}$, which in this paper is further referred to as dissolved organic $\mathrm{C}$, was extracted from the same sample set with deionized water using a 2:1 (water to soil) ratio by shaking at room temperature (Baker et al., 2000). The extracts were filtered using $0.22 \mu \mathrm{m}$ filters and DOC concentration was measured using wet persulfate oxidation (Menzel and Vaccaro, 1964) on a TOC analyzer (Oceanographic International, College Station, TX). Decomposable or bioavailable DOC (BDOC) was determined by inoculating a subsample of extracted DOC with microorganisms back-flushed from filters used to prepare DOC samples and incubating sample in the dark for 30 days (Servais et al., 1987; Baker et al., 2000). Following incubations, the remaining DOC content was measured using wet persulfate oxidation as described above, and BDOC was calculated as the difference between initial and final DOC concentration. DOC quality in terms of aromaticity was determined as specific ultra violet absorbance (SUVA) at $254 \mathrm{~nm}$ (Westerhoff and Anning, 2000).

The relative decomposability of SOC was determined from long-term aerobic laboratory incubation (Paul et al., 2001) of mineral soil samples taken in 2002 from the three upper mineral horizons in the five pedons. Approximately $80 \mathrm{~g}$ of field-moist, unsieved soil was incubated aerobically at $25{ }^{\circ} \mathrm{C}$ in glass jars (two laboratory replicates per sample). Two blanks 
(incubation jars without soil) were included in the design. Incubation jars were aerated weekly and soils were periodically weighed and water added to maintain initial soil moisture contents. $\mathrm{CO}_{2}$ evolution was measured periodically (initially, weekly, or biweekly for the first 8 weeks and monthly thereafter) using sodalime as a $\mathrm{CO}_{2}$ trapping agent. A correction factor of 1.41 was applied to weight differences to account for water loss during drying of sodalime at $105^{\circ} \mathrm{C}$ (Edwards, 1982; Zibilske, 1994). For simplicity sake, the pedons will be identified by their vegetation cover throughout the rest of the paper.

\section{Results and discussion}

\subsection{Soil morphology and genesis}

As expected, forest soils had characteristic $\mathrm{O}$ horizons (Table 1). These were thickest and most pronounced where conifers were present $[\leq 6 \mathrm{~cm}$ under spruce-fir forest (C-0a, C-0b, C-1, C-2), $\leq 5 \mathrm{~cm}$ under mixed conifer-aspen forest (AC-0, AC-1)] (Fig. 1). The $\mathrm{O}$ horizons were generally thinner $(\leq 3 \mathrm{~cm})$ in soils under aspen (A-0, A-1, A-2), reflecting the more easily decomposable foliage (e.g., Stump and Binkley, 1993; Prescott et al., 2000). Rangeland soils, i.e., soils under grass-forb (G-0a, G-0b, G-2, GC-2) and sagebrush cover (S-1, S-2), lacked O horizons. All soils had A horizons. Surprisingly, there was little difference in the thickness of A horizons (A plus AB transition horizons) between soils of rangeland (meadow, sagebrush) and conifer ecosystems. The A horizon thickness ranged from 31 to $35 \mathrm{~cm}$ under sagebrush, 12 to $36 \mathrm{~cm}$ under conifers, 17 to $29 \mathrm{~cm}$ under grass-forb meadows, and was about $19 \mathrm{~cm}$ in the ecotone between conifer forest and meadow. Soils under aspen had a slightly thinner A horizons (6-15 cm under aspen; 6-8 $\mathrm{cm}$ under mixed aspen-conifer). The color of A horizons in most soils were similar (dry 10YR to 7.5YR hue, 4-6 value), except in one grass-forb meadow soil (G-0b) located in a slight water- and sediment-gathering concavity which was darker (dry 2.5YR to 5YR hue, 3 value).

Soils under forest vegetation or shade tended to have thicker $\mathrm{E}$ and $\mathrm{EB}$ or $\mathrm{BE}$ transition horizons, indicating more leaching. This is consistent with previous research in two subalpine grass-forb meadows in the TWDEF which showed that upper horizons retained moisture longer following spring snowmelt in soil shaded by spruce-fir tree islands compared to exposed meadow soils (Van Miegroet et al., 2000). Two aspen pedons on steep slopes (A-0, A-1; 22-27\% slopes) lacked E horizons, likely caused by higher rates of runoff and erosion. Most rangeland soils lacked E horizons; greater belowground biomass and fine-root turnover coupled with less leaching resulted in the junction of $\mathrm{A}$ and $\mathrm{B}$ horizons.

All soils demonstrated an accumulation of clay in the subsoil and had B or B transition horizons (Bt, BEt) most of which classified as argillic horizons (Soil Survey Staff, 1999). Base cations were also high in the subsoil (data not shown). Thus, most soils were Alfisols. Some soils under aspen and grass-forbs that had dark surface horizons at least $18-\mathrm{cm}$ deep and $\mathrm{pH}$ about 6 or higher throughout their depth were Mollisols. The temperature regime of most soils was classified as cryic $\left(\sim 4{ }^{\circ} \mathrm{C}\right.$ mean annual soil temperature and relatively cool summer soil temperatures) and the moisture regime as udic (moist for most of the year). Soils under sagebrush were slightly warmer (frigid temperature regime: $\sim 5^{\circ} \mathrm{C}$ mean annual soil temperature, relatively warm summer soil temperature) and drier (xeric moisture regime: dry in the upper part for at least 45 consecutive days after the summer solstice).

Limited water movement plays a significant role in soil development in this environment. Soils under conifer forests did not develop into Spodosols primarily because of lack of sufficient water flux through the soil during a significant part the year. Alfisols and Mollisols are more typical of forest and rangeland soils seasonally dry environments; their high base status demonstrates that nutrient leaching losses are low due to moisture restrictions.

\subsection{SOC pools and distribution in the mineral soil}

Both soil organic matter (data not shown) and OC concentrations were highest in the upper part of the mineral soil and decreased with depth (Table 1). The $\mathrm{OC}$ concentration in the upper A horizon near the soil surface was higher in the forest pedons (35$\left.68 \mathrm{mg} \mathrm{g}^{-1}\right)$ and lowest in the sagebrush pedon $\left(16 \mathrm{mg} \mathrm{g}^{-1}\right)$. The OC concentration declined sharply with depth in the forest soils, especially under aspen, 
Table 1

Morphological, physical, and chemical properties of soil pedons sampled in 2002

\begin{tabular}{|c|c|c|c|c|c|c|c|c|c|c|}
\hline Horizon & $\begin{array}{l}\text { Depth } \\
(\mathrm{cm})\end{array}$ & $\begin{array}{l}\text { Color } \\
\text { (dry) }\end{array}$ & $\begin{array}{l}\mathrm{C} \\
\left(\mathrm{mg} \mathrm{g}^{-1}\right)\end{array}$ & $\begin{array}{l}\mathrm{N} \\
\left(\mathrm{mg} \mathrm{g}^{-1}\right)\end{array}$ & $\begin{array}{l}\text { Molar } \\
\text { C/N }\end{array}$ & $\begin{array}{l}\text { Field } \\
\mathrm{pH}\end{array}$ & $\begin{array}{l}\text { Field } \\
\text { texture }\end{array}$ & $\begin{array}{l}\text { Clay } \\
(\%)\end{array}$ & $\begin{array}{l}\text { Volume } \\
\geq 2 \text {-mm }(\%)\end{array}$ & $\begin{array}{l}\text { Estimated bulk } \\
\text { density }\left(\mathrm{Mg} \mathrm{m}^{-3}\right)\end{array}$ \\
\hline \multicolumn{11}{|c|}{ Conifer (C-2): Loamy-skeletal, mixed, superactive Umbric Haplocryalf } \\
\hline $\mathrm{Oi}$ & $0-5.5$ & nd & nd & nd & nd & nd & na & na & na & na \\
\hline A (with O) & $5.5-7$ & $10 \mathrm{YR} 3 / 2$ & 67.6 & 3.35 & 24 & 5.6 & gr L & 15 & 0 & 1.2 \\
\hline $\mathrm{A} 1$ & $7-17$ & 10YR $5 / 3$ & 15.6 & 0.66 & 28 & 5.4 & gr L & 15 & 20 & 1.3 \\
\hline A2 & $17-42$ & 10 YR $5 / 3$ & 13.2 & 0.61 & 25 & 5.4 & gr L & 13 & 15 & 1.3 \\
\hline $\mathrm{E}$ & $42-61$ & 10YR 6/3 & 5.6 & 0.12 & 53 & 4.8 & gr L & 12 & 17 & 1.3 \\
\hline $\mathrm{EB}$ & $61-76$ & $7.5 Y R \quad 7 / 4$ & 1.9 & $<0.10$ & - & 4.8 & gr LS & 10 & 30 & 1.5 \\
\hline Bt1 & $76-112$ & 7.5YR 6/4 & 2.0 & $<0.10$ & - & 4.6 & vst SL & 13 & 50 & 1.3 \\
\hline Bt2 & $112-150$ & 7.5 YR $6 / 4$ & 2.2 & $<0.10$ & - & 4.6 & vgr SL & 16 & 50 & 1.5 \\
\hline \multicolumn{11}{|c|}{ Aspen (A-2): Fine, smectitic Typic Haplocryalf } \\
\hline $\mathrm{Oi}$ & $0-1$ & nd & nd & nd & nd & nd & na & na & nd & na \\
\hline A1 & $1-4$ & $10 \mathrm{YR} 6 / 3$ & 34.6 & 1.95 & 21 & 6.0 & gr L & 14 & 15 & 1.2 \\
\hline $\mathrm{A} 2$ & $4-16$ & $10 \mathrm{YR} 6 / 3$ & 13.8 & 0.85 & 19 & 6.2 & gr SiL & 13 & 15 & 1.3 \\
\hline E1 & $16-33$ & $10 \mathrm{YR} 7 / 3$ & 5.3 & 0.34 & 18 & 5.4 & $\operatorname{vgr} \mathrm{L}$ & 11 & 55 & 1.3 \\
\hline E2 & $33-54$ & 10YR 7/3 & 1.8 & $<0.10$ & - & 5.2 & xcb SiL & 10 & 70 & 1.3 \\
\hline $\mathrm{BEt}$ & $54-68$ & $2.5 \mathrm{YR} 4 / 6$ & 2.7 & 0.19 & 17 & 5.1 & SCL & 28 & 5 & 1.4 \\
\hline $\mathrm{Bt}$ & $68-98$ & $10 \mathrm{R} 4 / 6$ & 1.7 & $<0.10$ & - & 5.1 & $\mathrm{C}$ & 52 & 0 & 1.5 \\
\hline$E^{\prime}$ & $98-102$ & 7.5 YR $8 / 4$ & 1.1 & $<0.10$ & - & 4.9 & SL & 18 & 0 & 1.3 \\
\hline BE't & $102-130$ & $2.5 \mathrm{YR} 6 / 6$ & 1.0 & 0.11 & 10 & 4.8 & $\mathrm{CL}$ & 36 & 0 & 1.4 \\
\hline
\end{tabular}

Meadow-conifer ecotone (GC-2): Fine-loamy, mixed, superactive Oxyaquic Haplocryalf

$\begin{array}{lllllllllll}\text { A1 } & 0-13.5 & 10 \text { YR 5/4 } & 19.7 & 0.98 & 23 & 5.4 & \text { gr L } & 19 & 20 & 1.2 \\ \text { A2 } & 13.5-18.5 & 10 \text { YR 5/3 } & 16.5 & 0.86 & 22 & 5.4 & \text { L } & 18 & 5 & 1.3 \\ \text { E } & 18.5-38.5 & 10 \text { YR 7/3 } & 8.7 & 0.40 & 26 & 5.6 & \text { vst L } & 19 & 55 & 1.3 \\ \text { EBt } & 38.5-53 & 10 \text { YR 7/3 } & 3.0 & 0.11 & 33 & 5.8 & \text { SCL } & 21 & 10 & 1.3 \\ \text { Bt } & 53-78 & 10 \text { YR 6/3 } & 3.5 & 0.17 & 24 & 5.5 & \text { st CL } & 33 & 20 & 1.4 \\ \text { Bt/E1 } & 78-94 & 7.5 \text { YR 4/4 } & 3.1 & 0.13 & 27 & 5.4 & \text { CL } & 35 & 5 & 1.4 \\ \text { Bt/E2 } & 94-110 & 7.5 \text { YR 4/4 } & 3.4 & <0.10 & - & 5.3 & \text { CL } & 30 & 5 & 1.4 \\ \text { E/Bt } & 110-136 & 7.5 Y R ~ 4 / 4 & 2.3 & 0.10 & 26 & 5.3 & \text { gr SCL } & 30 & 15 & 1.4 \\ \text { B't } & 136-160 & \text { 5YR 5/6 } & 1.4 & <0.10 & - & 4.8 & \text { SC } & 43 & 0 & 1.5\end{array}$

Grass forb meadow (G-2): Fine, smectitic Umbric Palecryalf

$\begin{array}{lllllllllll}\text { A1 } & 0-11 & \text { 10YR 4/4 } & 23.4 & 1.40 & 20 & 5.0 & \text { SL } & 26 & 5 & 1.2 \\ \text { A2 } & 11-18 & \text { 10YR 4/3 } & 20.5 & 1.30 & 18 & 5.0 & \text { SL } & 28 & 5 & 1.4 \\ \text { A3 } & 18-28 & \text { 10YR 4/3 } & 11.0 & 0.87 & 15 & 5.3 & \text { SCL } & 29 & 12 & 1.4 \\ \text { E } & 28-50 & \text { 10YR 5/3 } & 9.2 & 0.69 & 16 & 5.1 & \text { SCL } & 36 & 7 & 1.4 \\ \text { EBt } & 50-73 & \text { 10YR 7/4 } & 2.9 & <0.10 & - & 5.0 & \text { cb SCL } & 23 & 20 & 1.3 \\ \text { Bt1 } & 73-92 & 2.5 \text { YR 5/6 } & 1.7 & <0.10 & - & 4.6 & \text { C } & 43 & 0 & 1.5 \\ \text { Bt2 } & 92-111 & 2.5 \text { YR 5/8 } & 1.4 & <0.10 & - & 4.5 & \text { SC } & 40 & 0 & 1.4 \\ \text { Bt3 } & 111-145 & \text { 10R 5/8 } & 1.0 & <0.10 & - & 4.5 & \text { C } & 43 & 0 & 1.5\end{array}$

Sagebrush (S-2): Fine, smectitic, frigid Ultic Haploxeralf

\begin{tabular}{lllllllllll} 
A1 & $0-16$ & 7.5 YR 5/3 & 15.8 & 0.99 & 19 & 5.4 & SiL & 22 & 15 & 1.2 \\
A2 & $16-31$ & $7.5 Y R ~ 5 / 3$ & 13.6 & 0.77 & 20 & 5.4 & SiL & 22 & 25 & 1.3 \\
EBt/Bt & $31-42$ & 7.5 YR 5/4 & 8.5 & 0.42 & 26 & 5.3 & CL & 42 & 21 & 1.5 \\
& $31-42$ & 5YR 5/4 & 4.8 & 0.22 & 23 & 5.1 & C & 33 & - & 1.4 \\
Bt1 & $42-61$ & 5YR 4/6 & 3.2 & 0.10 & 37 & 5.1 & CL & 36 & 0 & 1.4 \\
Bt2 & $61-82$ & 5YR 4/6 & 1.7 & $<0.10$ & - & 4.7 & C & 49 & 0 & 1.5 \\
Bt3 & $82-129$ & 2.5YR 4/6 & 1.3 & $<0.10$ & - & 4.7 & C & 52 & 0 & 1.5 \\
\hline
\end{tabular}

Abbreviations: nd: not determined, na: not applicable, v: very, $\mathrm{x}$ : extremely, gr: gravelly, cb: cobbly, st: stony, bd: bouldery, LS: loamy sand, LFS: loamy fine sand, SL: sandy loam, FSL: fine sandy loam, COSL: coarse sandy loam, SiL: silt loam, L: loam, CL: clay loam, SCL: sandy clay loam, SiCL: silty clay loam, C: clay, SC: sandy clay, and SiC: silty clay. 
where the soil OC concentration dropped to $5 \mathrm{mg} \mathrm{g}^{-1}$ below $16 \mathrm{~cm}$ soil depth. The OC concentrations were similar in soils under the grass-forb cover, irrespective of location in the open meadow or the forest-meadow ecotone, and remained elevated to a greater depth $(40-50 \mathrm{~cm})$. Below $60 \mathrm{~cm}$, OC concentrations did not differ much among pedons and typically ranged between 1 and $3 \mathrm{mg} \mathrm{g}^{-1}$ (Table 1).

The SOC concentrations in the conifer, aspen, and grass-forb meadow soils are similar to values reported earlier for the same study site (Schimpf et al., 1980; Van Miegroet et al., 2000). They are higher than for comparable horizons in sandy pine and prairie soils in southeastern Wisconsin (Quideau and Bockheim, 1996), but this may be partly due to the higher percent sand in soils at that study site. The SOC concentrations and their vertical distribution in grassforb meadow soils are within the range observed under native prairie vegetation in the Great Plains (Amelung et al., 1997). The A horizon concentrations are lower than in Mollisols and native grassland soils, but similar to cultivated grassland soils in Montana (Sims and Nielsen, 1986) and higher than beneath bluebunch wheatgrass in eastern Washington (Bolton et al., 1990, 1993). The SOC concentrations in the aspen pedon are similar to values for aspen soils in interior Alaska in reported by O'Neill et al. (2002). The A horizon $(0-16 \mathrm{~cm})$ SOC concentrations are significantly lower than measured in closed-canopy stands at similar elevation in the Rocky Mountains of Colorado (Giardina et al., 2001), but comparable to Ae concentrations reported for aspen in Saskachewan (Huang and Schoenau, 1996). The SOC concentrations under sagebrush are on the low end of values measured in upper $0-20 \mathrm{~cm}$ of sagebrush soils in eastern Oregon (Doescher et al., 1984), in eastern Washington (Bolton et al., 1993), and at various soil depths in Wyoming (Burke et al., 1987; Burke, 1989), but similar to those reported for Utah (Charley and West, 1975).

Estimated total SOC in this forest-meadow mosaic ranged from a low of $50 \mathrm{Mg} \mathrm{ha}^{-1}(0-130 \mathrm{~cm})$ in the aspen pedon to a high of $109 \mathrm{Mg} \mathrm{ha}^{-1}(0-145 \mathrm{~cm})$ in the grass-forb pedon (Fig. 2). The total SOC was similar under conifer, sagebrush and in the meadowforest ecotone, around $85 \mathrm{Mg} \mathrm{ha}^{-1}$. In all cases, more than $50 \%$ of the total mineral soil $\mathrm{C}$ pool was contained in the A horizons (upper $30-40 \mathrm{~cm}$ ). The aspen pedon was somewhat of an outlier in that had a lower SOC pool, half of which was stored in the upper $16 \mathrm{~cm}$ of the mineral soil. Soil $\mathrm{N}$ was primarily concentrated in the upper $50-60 \mathrm{~cm}$ of the mineral soil (Table 1), following patterns in SOC accumulation. The $\mathrm{C} / \mathrm{N}$ ratio fluctuated around 20 (range: 15-28) in the upper soil horizons and did not differ among pedons.

Our calculated total SOC values fall within the range of worldwide averages for desert shrub, sclerophyllous scrubland, and temperate grasslands and woodlands (Lal et al., 1997; Jobbagy and Jackson, 2000), and those reported for forest-prairie ecotones in Missouri (Hammer et al., 1995). The SOC contained in the upper $50 \mathrm{~cm}$ of grass-forb and meadow-conifer ecotone soils and in the A horizon of the conifer soil is on the high end of values reported for Wisconsin prairie and pine soils, respectively (Quideau and Bockheim, 1996). Our SOC estimate for the conifer pedon $(0-150 \mathrm{~cm})$ is midway between values for the upper $100 \mathrm{~cm}$ of Alfisols and Spodosols in Denmark (Verje et al., 2003). It is within the range reported in the Great Lakes States for pines, but below those for balsam fir, and intermediate between black and white spruce in Alaska (O'Neill et al., 2002). Our aspen pedon estimate, however, is considerably lower than published values (Grigal and Ohman, 1992; Rollinger et al., 1997; O'Neill et al., 2002), and could be the result of the higher gravel content in the upper $50 \mathrm{~cm}$ (depth-weighted about $48 \%$ compared to $10-30 \%$ for the other pedons). Total SOC in the upper $15 \mathrm{~cm}$ under sagebrush falls in the middle of values reported by Burke (1989) for sites in Wyoming. The lower SOC accumulations in forest pedons at our site may be due to water limitations on NPP (Knight, 1991) and/or lower stand densities. Also, the reported SOC pools here are our best approximations based on estimated bulk density and coarse fragment volume, which are known to contribute to significant variation in total SOC (Hammer et al., 1995; Homann et al., 1995).

\subsection{SOC quality}

Are these SOC pools similar in stability and behavior, or could some of the observed differences in $\mathrm{C}$ accumulation be tied back to distinct SOC quality characteristics? Are SOC quality differences important to stability and retention of SOC in the different 


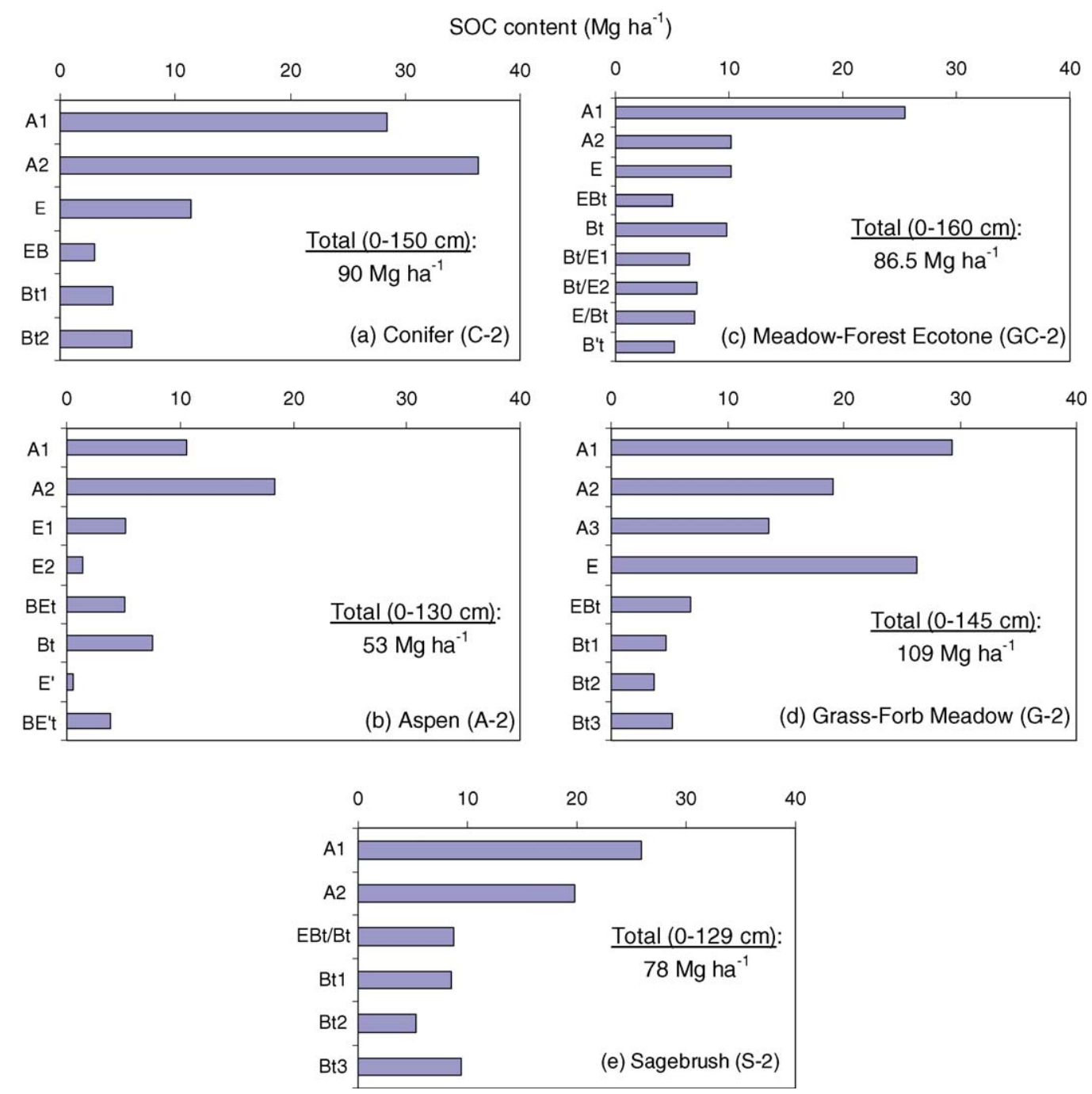

Fig. 2. Total SOC $\left(\mathrm{Mg} \mathrm{ha}^{-1}\right)$ by genetic horizon in the (a) conifer, (b) aspen, (c) meadow-forest ecotone, (d) grass-forb meadow, and (e) sagebrush pedon.

ecosystems? We specifically considered indicators of potential $\mathrm{C}$ losses as $\mathrm{CO}_{2}$ via microbial decomposition and as DOC via leaching.

Water-extractable OC levels (DOC) used as an indicator for SOC solubility and leaching potential, were significantly different among pedons $(p=0.004$; $\log -\log$ transformated to account for large and unequal within-pedon variance). The highest DOC concentrations were measured in the upper horizons of the forest soils, consistent with higher total OC concentrations close to the surface of forest soils.
Conifer DOC levels averaged $0.03 \mathrm{mg} \mathrm{g}^{-1}$, similar to those reported for Douglas-fir in Oregon (Jandl and Sollins, 1997). The aspen pedon consistently yielded higher DOC throughout the soil profile in 2002 (Fig. 3). The DOC was $2.5 \mathrm{mg} \mathrm{g}^{-1}$ in the upper few $\mathrm{cm}$, decreased to $0.03 \mathrm{mg} \mathrm{g}^{-1}$ in the E horizon (24$60 \mathrm{~cm}$ ), then increased again below $60 \mathrm{~cm}$ depth. This pattern possibly reflects downward transport of DOC from the upper SOM-rich horizons and relative accumulation, associated with a decline in hydraulic conductivity at the interface with the argillic horizon 


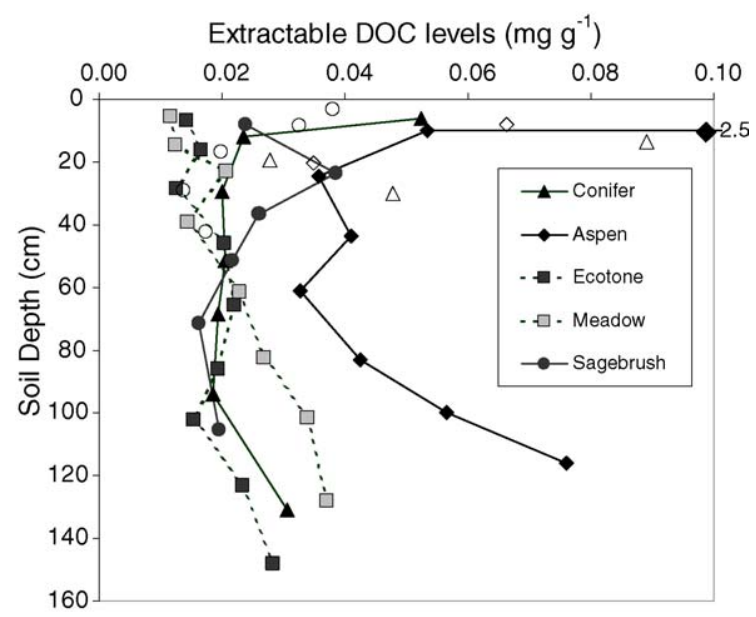

Fig. 3. Water-extractable DOC concentrations ( $\mathrm{mg} \mathrm{g}^{-1}$ dry soil) in the different soil pedons. Open symbols refer to 2001 near-surface soil samples; solid symbols to 2002 soil samples; DOC depth profiles are linked by lines [meadow, grass-forb meadow; ecotone, meadow-forest ecotone].

and/or DOC precipitation to the clay surfaces (e.g., Schoenau and Bettany, 1987; Quideau and Bockheim, 1996). The DOC levels in the upper A $(0-4 \mathrm{~cm})$, which likely contained some $\mathrm{O}$ horizon material, are similar to water-soluble SOC concentrations (considered equivalent to DOC in our study) measured in September-October in the organic F (1.2-3.1 $\mathrm{mg} \mathrm{g}^{-1}$ ) and $\mathrm{H}\left(0.9-1.9 \mathrm{mg} \mathrm{g}^{-1}\right)$ layers under aspen forests in Saskatchewan (Huang and Schoenau, 1996). That study also showed a sharp decline in DOC with depth, concentrations around $0.06-0.08 \mathrm{mg} \mathrm{g}^{-1}$ in the $\mathrm{Ae}$, and the highest DOC in October. Such a spatial and temporal pattern reflects the mobilization of soluble OC as the first step in the decomposition of fresh litter commonly observed in forests (Schoenau and Bettany, 1987; Qualls et al., 1991; Homann and Grigal, 1992; Hongve et al., 2000). The lower DOC in the conifer pedon compared to the aspen pedon is consistent with the findings by Hongve et al. (2000), indicating that deciduous litter gives off proportionally more DOC than conifers under similar climate. The lowest DOC levels were measured in the upper $60 \mathrm{~cm}$ of grass-forb meadow and meadow-forest ecotone soils, while DOC concentrations in surficial sagebrush soils were intermediate. The differences in extractable DOC between forest and grass-forb meadow soils in our study are consistent with lysimeter data showing lower solubility of OC under grasses (e.g., Quideau and Bockheim, 1996).

The DOC was poorly correlated with SOM $\left(R^{2}=0.2 ; p=0.001\right)$ and uncorrelated with SOC concentrations $\left(R^{2}=0.01 ; p=0.55\right)$ suggesting that differences in DOC levels were not driven by OC quantity and distribution, but rather indicated inherent differences in SOC quality, notably differences in solubility, and associated differences in downward transport. Across the entire dataset (excluding the one aspen soil outlier with a DOC value of $2.5 \mathrm{mg} \mathrm{g}^{-1}$; Fig. 3), we found a significant positive linear relationship between the amount of labile (BDOC) and total DOC (Fig. 4), similar to observations in agricultural soils by Zslonay and Steindl (1991). However, there were distinct differences in the decomposability of the DOC among forest and rangeland soils: The DOC produced in soils under grass-forb cover was highly labile, as $100 \%$ DOC of in grass-forb meadow soils and $76-100 \%$ of DOC (mean: $89 \pm 9 \%)$ in meadow-conifer ecotone soils disappeared within a 30-day period during laboratory incubations. Horizons from the sagebrush pedon fell slightly below the 1:1 line, indicating slightly lower DOC decomposability (mean: $76 \pm 17 \%$ ) compared

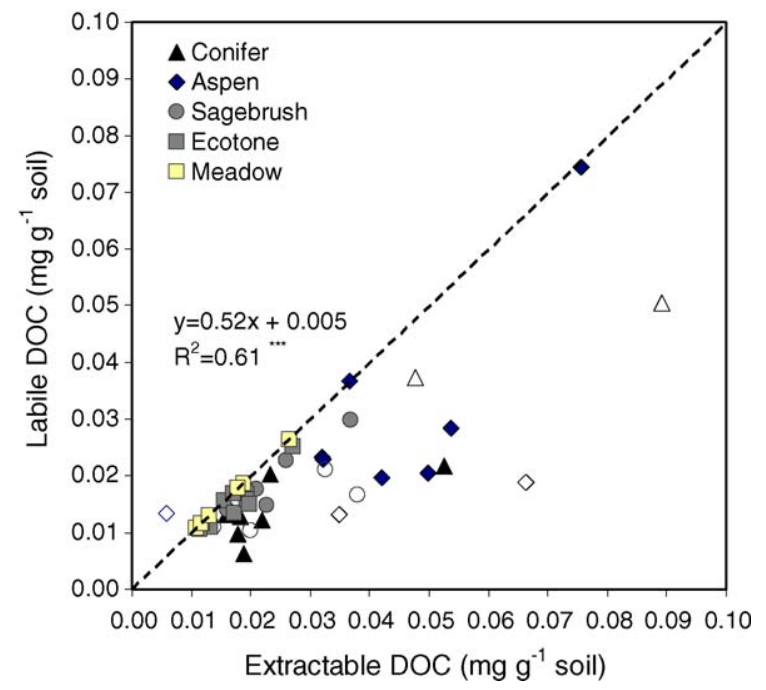

Fig. 4. Relationship between DOC concentrations ( $\mathrm{mg} \mathrm{g}^{-1}$ dry soil) and labile DOC (amount of DOC consumed during 30-day laboratory incubation in $\mathrm{mg} \mathrm{g}^{-1}$ dry soil) in soil samples collected under the different vegetation types. Open symbols refer to 2001 nearsurface soil samples; solid symbols to 2002 soil samples [meadow, grass-forb meadow; ecotone, meadow-forest ecotone]. 
to the grass-forb rangeland type. In contrast, the higher DOC levels extracted from the forest soils were also more stable compared to those from the rangeland soils, with \% decomposability ranging between 34 and $87 \%$ under conifer (mean: $62 \pm 19 \%$ ) and between 28 and $100 \%$ under aspen (mean: $60 \pm 24 \%$ ).

The DOC decomposition rates are in the general range of those noted for agricultural soils (Zslonay and Steindl, 1991). Our DOC decomposability values for forest soils are similar to those measured by Hongve et al. (2000) for various deciduous species during a 60day incubation $(\sim 60-70 \%)$, but higher than for spruce (nearly 0 ), or the $10-40 \%$ reported in the literature for pines and various hardwood species (Qualls and Haines, 1992; Yano et al., 1998; Corre et al., 1999). Our estimates for the decomposability of DOC in grass-forb soils are also higher than the $40 \%$ and 50\% reported for cool-season and warm-season grasses, respectively (Corre et al., 1999).

The SUVA readings expressed per mg DOC extracted showed considerable variability within each pedon (CV: 43-58\%). They were highest in the conifer soils (mean SUVA absorbance $\times 100 \mathrm{mg}^{-1}$ DOC: $3.9 \pm 1.3)$, and lowest in the grass-forb meadow (mean: $1.4 \pm 0.7$ ) and meadow-forest ecotone soils (mean: $1.3 \pm 0.6$ ), indicating that the DOC produced under conifers was relatively more aromatic compared to that produced under grasses and forbs. The aromaticity of DOC extracted from aspen (SUVA mean: $1.8 \pm 1.0$ ) and sagebrush soils (SUVA mean: $1.9 \pm 0.9$ ) was intermediate between that of conifer and grass-forb soils (Fig. 5). Hongve et al. (2000) similarly showed greater SUVA values for spruce compared to percolates from deciduous litter. Across all samples, the DOC decomposability and aromaticity as expressed by SUVA readings were inversely correlated $\left(N=46 ; R^{2}=0.26 ; p<0.001\right)$. This suggests a connection between $C$ structure and behavior, with a higher abundance of aromatic groups contributing to greater resistance of DOC to microbial decomposition, a conclusion also supported by Qualls and Haines (1992) and Hongve et al. (2000). Our data further suggest that low DOC levels in soils under grass-forb cover may, in part, be due to the rapid turnover of the soluble $\mathrm{C}$ by heterotrophic decomposers. The latter would lower the potential hydrologic $\mathrm{C}$ losses and, in effect, promote retention of $\mathrm{C}$ in the upper soil by continuously cycling the OC between

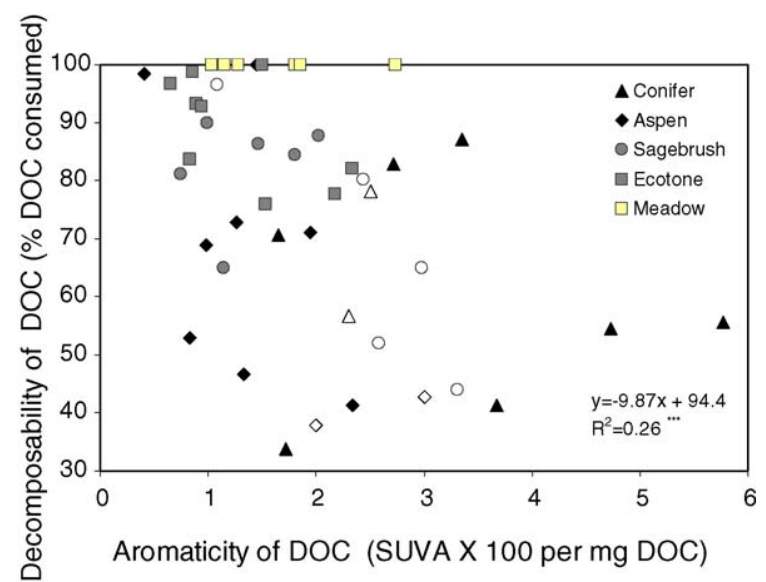

Fig. 5. Relationship DOC decomposability (\%DOC consumed during 30-day laboratory incubation) and DOC aromaticity (SUVA absorbance $\times 100$ per $\mathrm{mg}$ DOC) in soil samples collected under the different vegetation types. Open symbols refer to 2001 near-surface soil samples; solid symbols to 2002 soil samples [meadow, grassforb meadow; ecotone, meadow-forest ecotone].

the solid (microbial biomass) and the soluble phase. Microbial assimilation of DOC entails $\mathrm{C}$ losses as $\mathrm{CO}_{2}$, and the extent to which a decline in hydrologic losses (DOC leaching) is countered by an increase in gaseous losses (DOC decomposition) depends on the microbial $\mathrm{C}$ use efficiency and its controls. Because we did not measure DOC production rates in this study, we could not evaluate the role of differential DOC production rates in causing differences in DOC levels in this forest-rangeland mosaic. In modeling the controls of DOC flux and SOC content of forest soils, Neff and Asner (2001) showed soils with highly aromatic or hydrophobic DOC were less likely to leach given similar water availability. However, no correlation between DOC extracted and aromaticity emerged from our dataset $\left(R^{2}=0.01 ; p=0.42\right)$.

The cumulative $\mathrm{CO}_{2}$ release over the 10-month incubation was generally highest in the upper soil samples, especially in the forest soils (Fig. 6a). As was the case for total and soluble OC, forest soils exhibited a sharp change in SOC turnover with increasing depth below the soil surface. Differences in cumulative $\mathrm{CO}_{2}$ production between the upper three horizons were generally less pronounced in the rangeland soils. Daily $\mathrm{CO}_{2}$ evolution rates normalized for $\mathrm{OC}$ content indicated qualitative differences of the SOC across the landscape (Fig. 7). The initial amounts of $\mathrm{CO}_{2}$ 

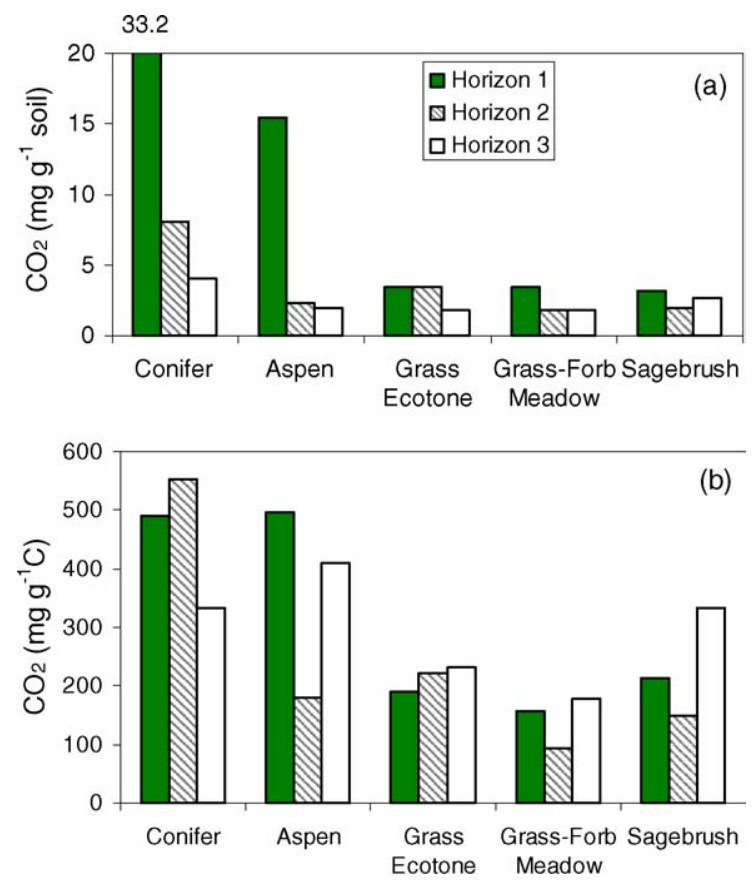

Fig. 6. Total amount of $\mathrm{CO}_{2}$ released $\left(\mathrm{mg} \mathrm{CO}_{2} \mathrm{~g}^{-1}\right.$ soil) (a) and total $\mathrm{CO}_{2}$ release per gram $\mathrm{C}$ (b) during 10 months of aerobic incubation of upper three mineral soil horizons from the five soil pedons.

released per $\mathrm{g}$ of $\mathrm{OC}$ were highest in the upper two mineral horizons $(5-17 \mathrm{~cm})$ of the conifer soil and the upper $4 \mathrm{~cm}$ under aspen. They declined exponentially with time, and by the end of the incubation period, $\mathrm{CO}_{2}$ evolution rates had dropped to around $1 \mathrm{mg} \mathrm{CO}_{2} \mathrm{~g}^{-1} \mathrm{C}$ $24 \mathrm{~h}^{-1}$. The cumulative $\mathrm{CO}_{2}$ release per unit $\mathrm{C}$ was quite comparable for upper forest soil horizons, ranging between 500 and $550 \mathrm{mg} \mathrm{g}^{-1} \mathrm{C}$ over 10 months and representing a little over $13 \%$ loss of SOC through decomposition (Fig. 6b). These cumulative and temporal trends were similar to those reported by Giardina et al. (2001) for the upper $15 \mathrm{~cm}$ of pine and aspen soils in The Rocky Mountains. The $\mathrm{CO}_{2}$ release rates from grass-forb meadow and meadow-forest ecotone soils were generally lower throughout the

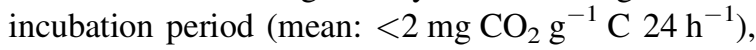
did not decline sharply with time, and did not differ among three soil horizons. The observed respiration kinetics suggests a higher content of labile $\mathrm{C}$ in the upper forest soils (Zak et al., 1993). Ross et al. (1999) similarly observed a sharp decline in respiration with increasing depth in pine soils, although their rates were substantially higher than those reported here. In another study they also measured greater $\mathrm{CO}_{2}$ release only in upper forest soils compared to grasslands in montane sites in New Zealand, with differences between vegetation type diminishing below $10 \mathrm{~cm}$ (Ross et al., 1996).

Sagebrush soils showed somewhat higher $\mathrm{CO}_{2}$ release rates at the onset of the incubation, as was also observed by Burke et al. (1989a). Overall, there were no strong differences between daily release rates among horizons (Fig. 7). Cumulative $\mathrm{CO}_{2}$ release per unit OC suggested that the EBt horizon $(32-42 \mathrm{~cm})$ in the sagebrush pedon contained more labile SOC compared to the overlying A horizons (Fig. 6b). The daily respiration rates for rangeland soils are in the line with literature values for Alaska tussock and shrub soils (Neff and Hoper, 2002), higher than soils in Utah recently established with sagebrush and crested wheatgrass (Chen and Stark, 2000), but around five times lower than for various sagebrush soils in Wyoming (Burke et al., 1989a). While the use of sodalime as a $\mathrm{CO}_{2}$ trap may have underestimated actual $\mathrm{CO}_{2}$ production rates, similar environmental conditions during the laboratory incubations would not have influenced trapping efficiency (Knoepp and Vose, 2002), such that our estimates correctly reflect relative differences among soil samples.

Our results suggest that there is a difference in SOC quality and its depth gradient across this heterogeneous landscape likely induced by differences in vegetation cover. Forest soils contain more labile (easily decomposable) $\mathrm{C}$ in the upper $\mathrm{A}$ horizons which is decomposed within a matter of weeks, and likely originates from translocation of SOC and DOC from the overlying $\mathrm{O}$ horizon. The SOC in rangeland soils under grass-forb cover is more uniform in quality and distribution and primarily composed of more recalcitrant SOC, as indicated by the lower and less time-dependent $\mathrm{CO}_{2}$ release rates per unit $\mathrm{C}$ present. This is consistent with $\mathrm{C}$ input from root turnover within the soil profile (Swift et al., 1979; Knight, 1991), as well as the concept of greater SOC stabilization in grassland soils (Stevenson, 1982; Anderson and Coleman, 1985). The quality of SOC in sagebrush soils is intermediate between that of forest and grass-forb soils, while the depth profile of that SOC quality seems somewhat different from either system. Burke and co-workers have shown that SOC 

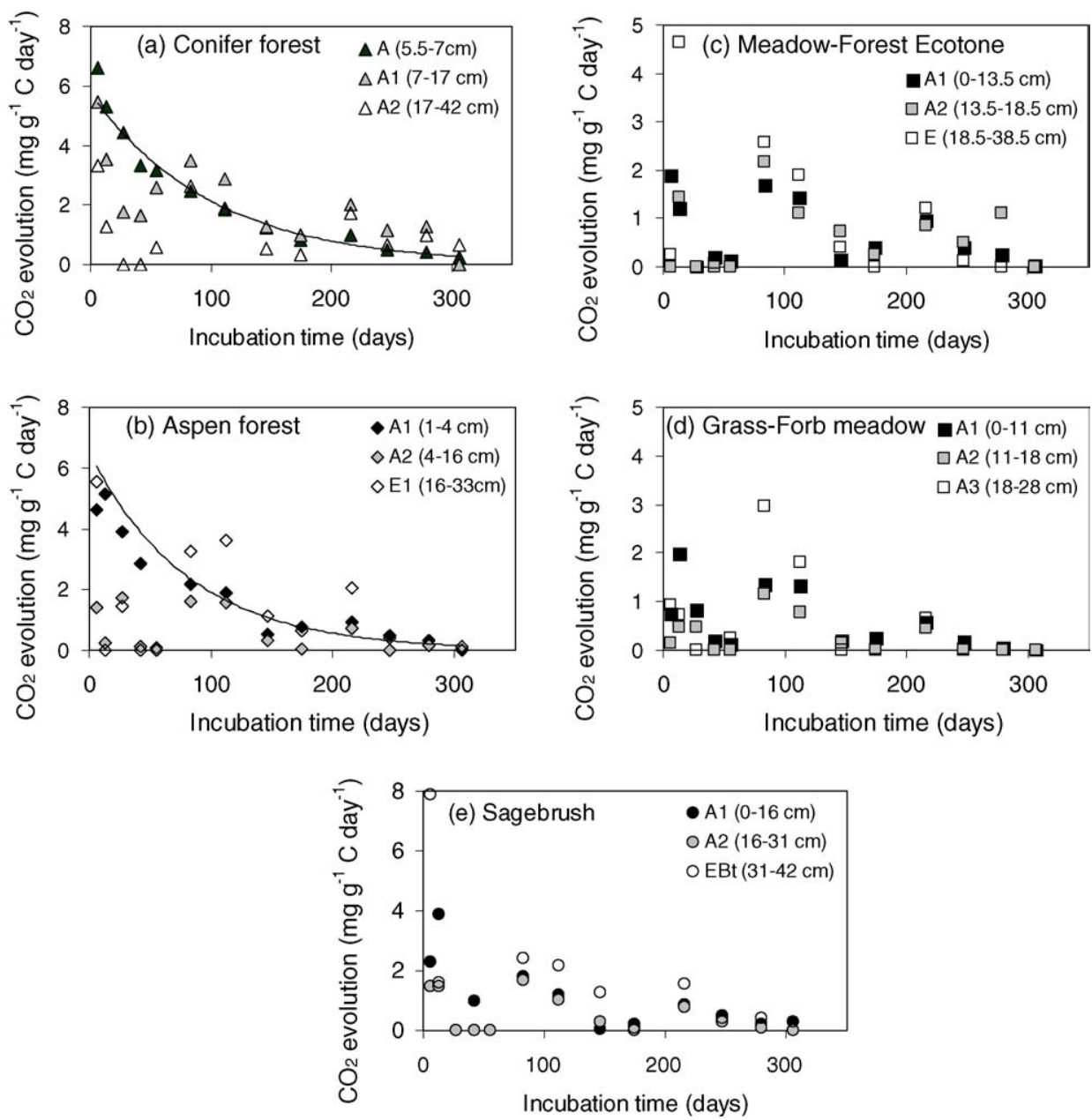

Fig. 7. Daily $\mathrm{CO}_{2}$ evolution rate, normalized for soil $\mathrm{C}$ content $\left(\mathrm{mg} \mathrm{CO}_{2} \mathrm{~g}^{-1} \mathrm{C} 24 \mathrm{~h}^{-1}\right)$ during aerobic incubation of the upper three mineral soil horizons of the (a) conifer, (b) aspen, (c) meadow-forest ecotone, (d) grass-forb meadow, and (e) sagebrush pedon.

content and dynamics can differ substantially between canopy-covered and interspace microsites in shortgrass and sagebrush steppes (Burke et al., 1989a; Hook et al., 1991; Vinton and Burke, 1995).

\section{Summary and conclusions}

We recognize that our data were obtained from a limited inference space $(<100 \mathrm{ha})$ and may therefore not necessarily represent the condition and behavior of similar ecosystems throughout the IMW. Also, the experimental design of this study (a single pedon sampled under each of five vegetation types for detailed SOC analysis) does not allow statistical inferences about vegetation influences on soil properties. Nevertheless, our results start to fill in some of the knowledge gaps regarding (1) spatial heterogeneity in SOC distribution and quality across patchy landscapes of this seasonally dry region and (2) potential differences between rangeland and forest ecosystems in the response of SOC stores to future global changes. Also, while SOC and DOC chemistry data are relatively abundant for forests and grasslands, much less information is available in the literature on the distribution and quality of SOC in sagebrush soils. 
The highest total SOC was calculated for the grassforb meadow soil, the smallest under aspen, but differences between rangeland and forest soils would have been smaller with the inclusion of $\mathrm{C}$ contained in the $\mathrm{O}$ horizon. Also, we do not have accurate estimates for the NPP and litter production rates for these particular ecosystems, and thus cannot unequivocally relate observed differences in SOC pools to differential loss rates alone. There are, nevertheless, distinct differences in the distribution and the quality of SOC that have a direct bearing on $\mathrm{C}$ stability and sensitivity to external disturbances. Greater SOC accumulation in the $\mathrm{O}$ horizon and closer to the surface in the mineral soil of forests in part reflects the aboveground litterfall input-decomposition cycle typical of forests. This surficial SOC would be particularly susceptible to losses during fires. Global change scenarios for the region predict an increase in fire probability (D'Antonio and Vitousek, 1992; Wagner, 2003). This could result in periodic reduction of the SOC pool, unless active fire suppression is implemented. It is expected that the SOC in the rangeland soils, which is stored more uniformly and deeply in the mineral horizons, would be less susceptible to such periodic fire disturbances.

We also found the SOC in rangeland soils to be less soluble, reducing potential losses through leaching; as well as more recalcitrant, reducing potential losses through decomposition. These inherent SOC characteristics, coupled with the fact that rangeland soils are generally drier and less conducive to decomposition during a large part of summer and early fall (Van Miegroet et al., 2000), likely contribute to greater SOC stability in open range areas under current conditions. Leaching of more aromatic and less biodegradable DOC in forest soils is an important mechanism of downward SOC translocation and potential loss from the soil. Aspen soils in particular had the highest extractable DOC levels in our study. Leaching losses, and the greater decomposability of particulate SOC could account for the lower SOC accumulation and the thinner A horizon under aspen. The lack of sufficient moisture currently limits the extent of DOC movement and nutrient leaching loss out of these soils, such that Spodosols seldom form, even under conifers. The surface soils under forests contain a significant amount of labile SOC that is easily lost as $\mathrm{CO}_{2}$ through microbial decomposition. This implies that on the whole, the capacity of these forest soils to retain SOC is lower than rangeland soils, and that current SOC losses (either through decomposition or through leaching) may largely be limited by the site water balance. Indeed, Conant et al. (2000) have shown that SOC decomposition in semi-arid environments is very responsive to increases in soil moisture.

Consequently, an increase in precipitation is likely to increase SOC losses from forest soils, at least in the short run. This may not be the case in the rangeland soils. The latter is to some extent substantiated by the fact that total C, DOC and other SOC characteristics in the conifer-meadow ecotone are almost identical to those of the grass-forb meadow soils. While these transition zones have a similar grass-forb vegetation cover and receive qualitatively similar $\mathrm{C}$ inputs, they are cooler and moister than the open grass-forb meadow due to shading by trees.

Our study illustrates that within the same regional climate and general soil matrix, there is notable heterogeneity in SOC distribution, quality and stability among soils under different vegetation types. Changes in soil microclimate, species composition, and fire cycles that may ensue from global climate change all can affect SOC pools. We speculate that the magnitude of the losses will be largely determined by the initial ecosystem conditions prior to disturbance, i.e., vegetation type and ensuing differences in SOC distribution and quality. Specifically, we suggest that SOC in rangeland soils is inherently more stable, while the SOC in forest soils is more likely to be lost, because (1) it is distributed closer to the surface, (2) it contains more labile components that can be lost through decomposition, and (3) the litter produces larger quantities of stable DOC that can be lost through deep leaching. The validity of our speculations and the generality of our conclusions need to be verified by characterizing SOC quantity, quality and distribution across a wider geographic area, and by measuring actual decomposition and leaching rates under field conditions.

\section{Acknowledgements}

Many thanks to Jedd Bodily for assistance with the soil analysis; to Jeremy Miner, Andrea Thurlow, and Ben Quick for their assistance with the laboratory 
incubations; to Agnes Chartier for assistance with the DOC analyses.

Funding for the soil incubation experiment was provided through the USU Ecology Center, funding for DOC analyses by the USU College of Science. AES Publication No. 7557, Utah Agricultural Experiment Station, Utah State University, Logan, Utah 84322-4810.

\section{References}

Amelung, W., Flach, K.W., Zech, W., 1997. Climatic effects on soil organic matter composition in the Great Plains. Soil Sci. Soc. Am. J. 61, 115-123.

Anderson, D.W., Coleman, D.C., 1985. The dynamics of organic matter in grassland soils. J. Soil Water Conserv. 40, 211216.

Bailey, R.G., 1998. Ecoregions: The Ecosystems and Geography of the Oceans and Continents. Springer-Verlag, NY, 176 pp.

Baker, M.A., Valett, H.M., Dahm, C.N., 2000. Organic carbon supply and metabolism in a shallow groundwater ecosystem. Ecology 81, 3111-3148.

Barth, R.C., Klemmedson, J.O., 1982. Amount and distribution of dry matter, nitrogen, and organic carbon in soil-plant systems of mesquite and palo verde. J. Range Manage. 35, 412-418.

Bolton, H., Smith, J.L., Wilding, R.E., 1990. Nitrogen mineralization potentials of shrub-steppe soils with different disturbance histories. Soil Sci. Soc. Am. J. 54, 887-891.

Bolton, H., Smith, J.L., Link, S.O., 1993. Soil microbial biomass and activity of a disturbed and undisturbed shrub-steppe soils ecosystem. Soil Biol. Biochem. 25, 545-552.

Bruce, J.P., Frome, M., Haites, E., Janzen, H., Lal, R., Paustian, K., 1999. Carbon sequestration in soils. J. Soil Water Conserv. 54, 382-389.

Burke, I.C., 1989. Control of nitrogen mineralization in a sagebrush steppe landscape. Ecology 70, 1115-1126.

Burke, I.C., Reiners, W.A., Schimel, D.S., 1989a. Organic matter turnover in a sagebrush steppe landscape. Biogeochemistry 7, $11-31$.

Burke, I.C., Reiners, W.A., Sturges, D.L., Matson, P.A., 1987. Herbicide treatment effects on properties of mountain big sagebrush soils after fourteen years. Soil Sci. Soc. Am. J. 51, 13371343.

Burke, I.C., Yonker, C.M., Parton, W.J., Cole, C.V., Flach, K., Schimel, D.S., 1989b. Texture, climate, and cultivation effects on soil organic matter content in U.S. grassland soils. Soil Sci. Soc. Am. J. 53, 800-805.

Charley, J.L., West, N.E., 1975. Plant-induced soil chemical patterns in some shrub-dominated semi-desert ecosystems of Utah. J. Ecol. 63, 945-964.

Chen, J., Stark, J.M., 2000. Plant species effects and carbon and nitrogen cycling in a sagebrush-crested wheatgrass soil. Soil Biol. Biochem. 32, 47-57.
Christ, M.J., David, M.B., 1996. Dynamics of extractable organic carbon in Spodosol forest floors. Soil Biol. Biochem. 28, 11711179.

Coleman, D.C., 1976. A review of root production processes and their influence on soil biota in terrestrial ecosystems. In: Anderson, J.M., MacFadyen, A. (Eds.), The Role of Terrestrial and Aquatic Organisms in Decomposition Processes. Blackwell Scientific Publications, Oxford, UK, pp. 417-434.

Conant, R.T., Klopatek, J.M., Klopatek, C.C., 2000. Environmental factors controlling soils respiration in three semiarid ecosystems. Soil Sci. Soc. Am. J. 64, 383-390.

Corre, M.D., Schnabel, R.R., Shaffer, J.A., 1999. Evaluation of soil organic carbon under forests, cool-season and warm-season grasses in the northeastern US. Soil Biol. Biochem. 31, $1531-1539$.

D’Antonio, C.N., Vitousek, P.M., 1992. Biological invasions by exotic grasses, the grass/fire cycle and global change. Annu. Rev. Ecol. Syst. 23, 63-87.

Doescher, P.S., Miller, R.F., Winward, A.H., 1984. Soil chemical patterns under eastern Oregon plant communities dominated by big sagebrush. Soil Sci. Soc. Am. J. 48, 659-663.

Dover, J.H., 1995. Geologic map of the Logan $30^{\prime} \times 60^{\prime}$ quadrangle, Cache and Rich Counties, Utah, and Lincoln and Uinta Counties, Wyoming. US Geological Survey, Denver, CO.

Edwards, N.T., 1982. The use of soda-lime for measuring respiration rates in terrestrial systems. Pedobiologia 23, 321-330.

Foth, H.D., 1984. Fundamentals of Soil Science. John Wiley and Sons, NY.

Gee, G.W., Bauder, J.W., 1986. Particle-size analysis. In: Page, A.L. (Ed.), Methods of Soil Analysis: Physical and Mineralogical Methods. Part 1. SSSA Book Series no. 5. Soil Science Society of America, Madison, WI, pp. 383-411.

Giardina, C.P., Ryan, M.G., Hubbard, R.M., Binkley, D., 2001. Tree species and soil texture controls on carbon and nitrogen mineralization rates. Soil Sci. Soc. Am. J. 65, 1272-1279.

Grigal, D.F., Ohman, L.F., 1992. Carbon storage in upland forest of the Lake States. Soil Sci. Soc. Am. J. 56, 935-943.

Guo, L.B., Gifford, R.M., 2002. Soil carbon stocks and land use change: a meta analysis. Global Change Biol. 8, 345-360.

Hammer, R.D., Henderson, G.S., Udawatta, R., Brandth, D.K., 1995. Soil organic carbon in the Missouri forest-prairie ecotone. In: Kelly, J.M., McFee, W.W. (Eds.), Carbon Forms and Functions in Forest Soils. Soil Science Society of America, Madison, WI, pp. 201-231.

Homann, P.S., Grigal, D.F., 1992. Molecular weight distribution of soluble organics from laboratory manipulated surface soils. Soil Sci. Soc. Am. J. 56, 1305-1310.

Homann, P.S., Sollins, P., Chappell, H.N., Stangenberger, A.G., 1995. Soil organic carbon in a mountainous, forested region: Relation to site characteristics. Soil Sci. Soc. Am. J. 59, 1468-1475.

Hongve, D., VanHees, P.A.W., Lindstron, U.S., 2000. Dissolved components in precipitation water percolated through forest litter. Eur. J. Soil Sci. 51, 667-677.

Hook, P.B., Burke, I.C., Lauenroth, W.K., 1991. Heterogeneity of soil and plant $\mathrm{N}$ and $\mathrm{C}$ associated with individual plants and openings in North American shortgrass steppe. Plant Soil 138, 247-256. 
Houghton, R.A., 1995. Changes in the storage of terrestrial carbon since 1850. In: Lal, R., Kimble, J., Levine, E., Stewart, B.A. (Eds.), Soils and Global Change. Lewis Publishers, Boca Raton, FL, pp. 45-65.

Huang, W.Z., Schoenau, J.J., 1996. Distribution of water-soluble organic carbon in an aspen forest soil. Can. J. Forest Res. 26, 1266-1272.

Jackson, R.B., Babber, J.L., Jobbagy, E.G., Pockman, W.T., Wall, D.H., 2002. Ecosystem carbon loss with woody plant invasions of grasslands. Nature 428, 623-626.

Jandl, R., Sollins, P., 1997. Water-extractable soil carbon in relation to the belowground carbon cycle. Biol. Fertil. Soils 25, 196-201.

Jobbagy, E.G., Jackson, R.B., 2000. Vertical distribution of soil organic carbon and its relation to climate and vegetation. Ecol. Appl. 10, 423-436.

Johnson, D.W., 1995. Soil properties beneath Ceanothus and pine stands in the eastern Sierra Nevada. Soil Sci. Soc. Am. J. 59, 918-924.

Johnson, D.W., Curtis, P.S., 2001. Effects of forest management on soil C and N storage: a meta analysis. Forest Ecol. Manage. 140, 227-238.

Kirschbaum, M.U.F., 1995. The temperature dependence of soil organic matter decomposition, and the effect of global warming on soil organic storage. Soil Biol. Biochem. 27, 753-760.

Knight, W.G., 1991. Chemistry of arid region soils. In: Skujins, J. (Ed.), Semiarid Lands and Deserts-Soil Resource and Reclamation. Marcel Dekker Inc., New York, pp. 111-171.

Knoepp, J.D., Vose, J.M., 2002. Quantitative comparison of in situ soil $\mathrm{CO}_{2}$ flux measurement methods. USDA-Forest Service Research Paper SRS-28. Southern Research Station, Asheville, NC.

Kononova, M.M., 1966. Soil Organic Matter: Its Nature, its Role in Soil Formation and in Soil Fertility. Pergamon Press, New York.

Lal, R., Kimble, J., Follett, R.F., 1997. Land use and soil C pools in terrestrial ecosystems. In: Lal, R., et al. (Eds.), Management of Carbon Sequestration in Soil. CRC Press, Boca Raton, FL, pp. $1-10$.

Manley, J.T., Schuman, G.E., Reeder, J.D., Hart, R.H., 1995. Rangeland soil carbon and nitrogen responses to grazing. J. Soil Water Conserv. 50, 294-298.

Menzel, D.W., Vaccaro, R.F., 1964. The measurement of dissolved and particulate organic carbon in seawater. Limnology Oceanography 9, 138-142.

Neff, J.C., Asner, G.P., 2001. Dissolved organic carbon in terrestrial ecosystems: synthesis and a model. Ecosystems 4, 29-48.

Neff, J.C., Hoper, D.U., 2002. Vegetation and climate controls on potential $\mathrm{CO}_{2}$, DOC and DON production in northern latitude soils. Global Change Biol. 8, 872-884.

Nelson, D.W., Sommers, L.E., 1996. Total carbon, organic carbon, and organic matter. In: Sparks, D.L., et al. (Eds.), Methods of Soil Analysis. Part 3. Chemical Methods. Soil Science Society of America, Madison, WI, pp. 961-1010.

O’Neill, K.P., Kasischke, E.S., Richter, D.R., 2002. Environmental controls on soil $\mathrm{CO}_{2}$ flux following fire in black spruce, white spruce, and aspen stands in interior Alaska. Can. J. Forest Res. $32,1525-1541$.
Paul, E.A., Morris, S.J., Bohm, S., 2001. The determination of soil C pool sizes and turnover rates: biophysical fractionation and tracers. In: Lal, R., Kimble, J.M., Follett, R.F., Stewart, B.A. (Eds.), Assessment Methods for Soil Carbon. Lewis Publishers, Boca Raton, FL, pp. 193-206.

Post, W.M., Emanuel, W.R., Zinke, P.J., Stangenberger, A.G., 1982. Soil carbon pools in world life zones. Nature 298, 156-159.

Prescott, C.E., Zabek, L.M., Staley, C.L., Kabzems, R., 2000. Decomposition of broadleaf and needle litter in forests of British Columbia: influence of litter type, forest type, and litter mixtures. Can. J. Forest Res. 30, 1742-1750.

Prichard, S.J., Peterson, D.L., Hammer, R.D., 2000. Carbon distribution in subalpine forests and meadows of the Olympic Mountains, Washington. Soil Sci. Soc. Am. J. 64, 1834-1845.

Qualls, R.G., Haines, B.L., 1992. Biodegradability of dissolved organic matter in forest throughfall, soil solution and stream water. Soil Sci. Soc. Am. J. 56, 578-586.

Qualls, R.G., Haines, B.L., Swank, W.T., 1991. Fluxes of dissolved organic nutrients and humic substances in a deciduous forest. Ecology 72, 254-266.

Quideau, S.A., Bockheim, J.G., 1996. Vegetation and cropping effects on pedogenic processes in a sandy prairie soil. Soil Sci. Soc. Am. J. 60, 536-545.

Quideau, S.A., Chadwick, O.A., Benesi, A., Graham, R.C., Anderson, M.A., 2001. A direct link between forest vegetation type and soil organic matter composition. Geoderma 104, 41-60.

Raich, J.W., Nadelhoffer, K.J., 1989. Belowground carbon allocation in forest ecosystems: global trends. Ecology 70, 1346-1354.

Rollinger, J.L., Strong, T.F., Grigal, D.F., 1997. Forested soil carbon storage in landscapes of the northern Great lakes region. In: Lal, R., et al. (Eds.), Management of Carbon Sequestration in Soil. CRC Press, Boca Raton, FL, pp. 335-350.

Ross, D.J., Kelliher, F.M., Tate, K.R., Feltham, C.W., 1999. Microbial processes in relation to carbon, nitrogen and temperature regimes in litter and a sandy mineral soil from central Siberian Pinus sylvestris L. forest. Soil Biol. Biochem. 31, 757-767.

Ross, D.J., Tate, K.R., Feltham, C.W., 1996. Microbial biomass, and $\mathrm{C}$ and $\mathrm{N}$ mineralization in litter and mineral soil of adjacent montane ecosystems in a southern beech (Nothofagus) forest and tussock grassland. Soil Biol. Biochem. 28, 1613-1620.

Schimel, D.S., Kittel, G.F., Running, S., Monson, R., Turnipseed, A., Anderson, D., 2002. Carbon sequestration studied in western U.S. Mountains. EOS, Trans. Am. Geophys. Union 83 (40) 445 and 449.

Schimpf, D.J., Henderson, J.A., MacMahon, J.A., 1980. Some aspects of succession in the spruce-fir forest zone of northern Utah. Great Basin Nat. 40, 1-26.

Schoenau, J.J., Bettany, J.R., 1987. Organic matter leaching as a component of carbon, nitrogen, phosphorus, and sulfur cycling in a forest, grassland, gleyed soil. Soil Sci. Soc. Am. J. 51, 646-651.

Servais, P., Billen, G., Hascoet, M.C., 1987. Determination of the biodegradable fraction of dissolved organic matter in waters. Water Res. 21, 445-450.

Sims, Z.R., Nielsen, G.A., 1986. Organic carbon in Montana soils as related to clay content and climate. Soil Sci. Soc. Am. J. 50, 1269-1271. 
Skujins, J., Klubek, B., 1982. Soil biological properties of a montane forest sere: Corroboration of Odum's postulates. Soil Biol. Biochem. 14, 505-513.

Soil Survey Division Staff, 1993. Soil Survey Manual. US Department of Agriculture Handbook No. 18. US Government Printing Office, Washington, DC.

Soil Survey Laboratory Staff, 1996. Soil Survey Laboratory Methods Manual. Soil Survey Investigations Report No. 42. US Government Printing Office, Washington, DC.

Soil Survey Staff, 1999. Soil Taxonomy: A Basic System of Soil Classification for Making and Interpreting Soil Surveys. USDA Natural Resources Conservation Service. Agriculture Handbook 436, second ed. US Government Printing Office, Washington, DC.

Stevenson, F.J., 1982. Humus Chemistry-Genesis, Composition, Reactions. John Wiley and Sons, NY.

Stump, L.M., Binkley, D., 1993. Relationship between litter quality and nitrogen availability in Rocky Mountain forests. Can. J. Forest Res. 23, 492-502.

Swift, M.J., Heal, O.W., Anderson, J.M., 1979. Decomposition in Terrestrial Ecosystems. University of California Press, Berkeley and Los Angeles, CA, 372 pp.

Tiedeman, A.R., 1987. Nutrient accumulation in pinyon-juniper ecosystems - managing for future site productivity. In: Everett, R.L. (Comp.), Proceedings Pinyon-Juniper Conference held in Reno, NV, January 13-16, 1986. USDA-FS Inter. Res. Stn. Gen Tech. Re INT-215, p. 352-359.

Van Miegroet, H., Hysell, M.T., Denton Johnson, A., 2000. Soil microclimate and chemistry of spruce-fir tree islands in northern Utah. Soil Sci. Soc. Am. 64, 1515-1525.

Verje, H., Callesen, I., Vesterdal, L., Raulund-Rasmussen, K., 2003. Carbon and nitrogen in Danish forest soils-contents and dis- tribution determined by soils order. Soil Sci. Soc. Am. 67, 335-343.

Vinton, M.A., Burke, I.C., 1995. Interactions between individual plant species and soil nutrient status in shortgrass steppe. Ecology 76, 1116-1133.

Wadleigh, L., Jenkins, M.J., 1996. Fire frequency and the vegetative mosaic of a spruce-fir forest in northern Utah. Great Basin Nat. $56,28-37$.

Wagner, F.H., 2003. Preparing for a changing climate-potential consequences of climatic variability and change. A Report of The Rocky Mountain/Great Basin Regional Assessment Team for the U.S. Global Change Research Program. Utah State University, Logan, Utah, 239 pp.

Westerhoff, P., Anning, D., 2000. Concentrations and characteristics of organic carbon in surface water in Arizona: Influence of urbanization. J. Hydrol. 236, 202-222.

Yano, Y., McDowell, W.H., Kinner, N.E., 1998. Quantification of biodegradable dissolved organic carbon in soil solution with flow-through bioreactors. Soil Sci. Soc. Am. J. 62, 1556-1564.

Zak, D.R., Grigal, D.F., Ohmann, L.F., 1993. Kinetics of microbial respiration and nitrogen mineralization in Great Lakes forests. Soil Sci. Soc. Am. J. 57, 1100-1106.

Zech, W., Haumaier, L., Koegel-Knabner, I., 1989. Changes in aromaticity and carbon distribution of soil organic matter due to pedogenesis. Sci. Total Environ. 81, 179-186.

Zibilske, L.M., 1994. Carbon mineralization. In: Weaver, et al. (Eds.), Methods of Soil Analysis. Part 2. Microbiological and Biochemical Properties. Agron. Monogr. 5. second ed. ASA, Madison, WI, pp. 835-863.

Zslonay, A., Steindl, H., 1991. Geovariability and biodegradability of the water-extractable organic material in an agricultural soil. Soil Biol. Biochem. 23, 1077-1082. 